\title{
Influence of flaking on feeding value of cereals for weaned pigiets and growing-finishing pigs
}

\section{J. CASTAING ${ }^{(1)}$, R. COUDURE ${ }^{(1)}$, J. FEKETE ${ }^{(2)}$, F. GROSJEAN ${ }^{(2)}$, J.L. VIALLET ${ }^{(3)}$}

(I) A.G.P.M., 122, boulevard Tourasse, 64000 Pau.

(2) I.T.C.F., 8, avenue du Président-Wilson, 75116 Paris.

(3) Coopérative Franciade, 11, rue Franciade, 41007 Blois.

Two trials involving respectively 1296 piglets between 9 and $25 \mathrm{~kg}$ live weight and 192 growing finishing pigs between 25 and $103 \mathrm{~kg}$ live weight were conducted to study the effect of flaking on the feeding value of three cereals: maize, wheat and barley. Diets were based on a single cereal (raw or flaked) supplemented with soybean meal, minerals and vitamins.

In weaned piglets, feed intake was $28 \%$ higher at the beginning of the trial and up to $16 \mathrm{~kg}$ with diets including a flaked cereal, but was slightly lower with diets based on a raw cereal so that growth of piglets was similar. On the whole experiment ( 28 days), flaking did not significantly affect feed intake and growth. Food conversion ratio was $1.83,1.85$ and 1.95 with diets based on raw maize, wheat and barley and $1.83,1.88$ and 1.97 with flaked maize, wheat and barley, respectively. In growing-finishing pigs subjected to a feeding pattern, flaking led to as significantly improved food conversion ratio $(2.5 \%)$. There was no significant interaction between the type of cereal and the physical form though flaking tended to be more efficient with wheat than with the other cereals : food conversion ratios of raw and flaked maize, wheat and barley diets were 3.05 , $3.16,3.35,3.02,3.05$ and 3.26 , respectively. Flaking slightly improved carcass yield by 0.2 point but did not affect carcass quality.

\section{Interaction between ambient temperature and dietary energy level on growth performance and utilization of energy in the pig}

\author{
J. NOBLET, J. LE DIVIDICH, T. BIKAWA
}

INRA, Station de Recherches Porcines, Saint-Gilles, 35590 L'Hermitage

A high energy diet (with supplemental fat) and a low energy diet (with supplemental wheat bran) were fed to 72 piglets maintained for six weeks after weaning at 28,22 and $16^{\circ} \mathrm{C}$ (experiment 1), to 54 growing-finishing pigs kept from 30 to $100 \mathrm{~kg}$ live weight at 28,20 and $12{ }^{\circ} \mathrm{C}$ (experiment 2) and to 32 growing pigs kept in respiration chamber at 13 and $23{ }^{\circ} \mathrm{C}$ (experiment 3 ). In ad libitum fed pigs (experiment 1), an interaction between dietary energy level and ambient temperature was observed : at $16^{\circ} \mathrm{C}$, DE intake and $\mathrm{DE}$ : gain were similar for both diets whereas at $28^{\circ} \mathrm{C} \mathrm{DE}$ intake was smaller and DE : gain higher with the low energy diet. Even though daily gains were similar at the three temperatures and with both diets (experiment 2), no significant interaction between dietary encrgy level and ambient temperature on growth performance and body composition was noticed. For each ${ }^{\circ} \mathrm{C}$ decrease in ambient temperature, food supply must be increased by 15 and $33 \mathrm{~g}$ between 28 and $20^{\circ} \mathrm{C}$ and between 20 and $12^{\circ} \mathrm{C}$, respectively to maintain a constant growth rate. At constant DE intakes (experiment 3), heat production was higher at $23{ }^{\circ} \mathrm{C}$ with the low energy diet and comparable with both diets at $13{ }^{\circ} \mathrm{C}$. However, improvement of $\mathrm{ME}$ utilization of low energy diets at low temperatures was only beneficial to fat deposition. 